\title{
INTEGRATED MANAGEMENT OF MEDICAL WASTE HANDLING STATE OF KUWAIT
}

\author{
Hewehy, M. A. ${ }^{(1)}$; Al Shiraifi, F. A. ${ }^{(2)}$ and Buhamad, Esraa, S. ${ }^{(3)}$ \\ 1) Institute of Environmental Studies \& Research, Ain Shams University \\ 2) The Public Authority for Applied Education and Training State of Kuwait \\ 3) Kuwait Ministry of Helth
}

\begin{abstract}
The objective of the study is to find available alternative methods to reach integrated healthcare waste management in the state of Kuwait. Such methods would minimize the risks result from medical waste that affects healthcare staff, public health, and the environment and to help bring the Kuwait ministry of health legislation closer to Kuwait Environment Public Authority standards and legislation. A survey among a sample of 386 staff of 6 governmental hospitals in state of Kuwait indicates that there is lack in cleaner's knowledge. A field visit to the governmental hospital indicates that there is a lack of provision of materials for the safe disposal of medical waste. Analyze 9 samples using (HRGC/HRMS) instrument indicate that emission of dioxin and furan is within (KPEA) limits, but the level of emissions is increase depending on different factors, also analyses 7 samples of bottom ash in (ICPOES) classified it as hazard waste. This study concludes that reduce (PCDD's and PCDF's) depend on human, technical legal factors, and using environmentally friendly alternatives methods instead of or assistant to the process of medical waste incineration.
\end{abstract}

Key words: Medical waste, management, hazardous/ Non-hazardous healthcare waste

\section{INTRODUCTION}

Every day around the world health care provider treat the sick saving their life, but they also generate a large amount of potentially hazardous waste, a study of (Alhumoud and Alhumoud, 2007) indicate that the generation medical waste in state of Kuwait is about 3.6 to $7.44(\mathrm{Kg} / \mathrm{bed} /$ day $)$. 
In state of Kuwait the issue of hazard medical waste becoming a serious concern for researchers, environmental and health authorities. Medical waste can remain toxic for generations if left untreated, these medical waste treatment need an integrated management. (Shortell and Kaluzny, 1988) says that the standard conception of the role of management can be described by the acronym PODC. The letters stand for Plan, Organized, Direct, and Control.

The technologies applied in state of Kuwait to treat medical waste are incinerator and steam sterilizations. There are three central incinerations in state of Kuwait; Incineration can concentrate inorganic toxic materials such as heavy metals in the waste in the ash residues (bottom ash and fly ash), Bottom ash makes up about 90 percent of the total ash produced during waste incineration (Amfo-Out, 2015) Incinerators release dioxin/furans to air via chimney (stack) exhaust and via fugitive releases, e.g., air leaks when charging the incinerator with fuel and/or waste. Dioxin and furans also may be contained in fly ash, in bottom ash and other dusts (though to a smaller extent), and in other waste streams. Dioxin/furan releases to air are believed to be the most significant exposure pathway (UNDP 2003). Air releases of dioxins/furans occur in both vapor and particulate phases (Batterman, 2004).

The most important issue that discuss in this paper research to reach integrated medical waste manage under the concept of Plan, Organized, Direct, and Control are the follow:

- Ensure the safe handling and collection and work place safety.

- (PCDD's and PCDF's) emissions. 
- Safe disposal of bottom /fly ash.

\section{MATRIALS AND METHODS}

5 methods are used to detect the system efficiency of health care waste management in the state of Kuwait:

1. Define the type and quantities of medical waste based on 3 month monitoring data of waste generation in Kuwait government's hospitals.

2. Questionnaire for healthcare staff in Kuwait hospitals. Take sample from 6 governmental hospitals of medical staff to identify the level of their awareness, safety practice by analyses the result of the survey in SPSS application version 20 .

3. Examine the efficiency of sterilization through biology test. Biological test is done by incubate an indicator ampoule.

4. Examination of gaseous emissions from incinerators (dioxins/furans) by using the OPSIS instrument. High resolution gas Chromatographic Column coupled to a high resolution mass spectrometer (HRGC/HRMS) using the instrumental parameters. An emission testing was conducted in accordance with procedures set forth in US EPA Title 40 CFR 60, Appendix A, Reference Methods (RM).

5. Examine bottom ash samples from incinerators to measure heavy metal using Inductivity couple plasma (ICPOES). 


\section{RESULT AND DISCUSSION}

The survey result was as the follow:

Concerning to awareness of hospital staff policy, as expected the cleaners were the least aware. The survey detects that only $5.2 \%$ of Cleaners surveyed were aware of such policy. Regard to total surveyed, 23.4 percent of staff answer correctly the 10 question of the labeling system. Color coding makes it easier for hospital workers to put waste items into the correct container (WOH, 2014). The survey indicates that majority of the staff recognized Color coding system. (Table 1) 
Table 1: Medical staff knlowdeg about Color coding system

\begin{tabular}{|c|c|c|c|c|}
\hline Position & & a. & $\mathrm{b}$. & c. \\
\hline Doctors & $\begin{array}{l}\text { Count } \\
\text { Within occupational group }(\%) \\
\text { Within color code }(\%) \\
\text { Percentage of total }(\%)\end{array}$ & $\begin{array}{l}19 \\
43.2 \\
7.88 \\
4.9\end{array}$ & $\begin{array}{l}34 \\
77.2 \\
12.8 \\
8.8\end{array}$ & $\begin{array}{l}21 \\
47.7 \\
10.2 \\
5.4\end{array}$ \\
\hline Nurses & $\begin{array}{l}\text { Count } \\
\text { Within occupational group (\%) } \\
\text { Within color code }(\%) \\
\text { Percentage of total }(\%) \\
\end{array}$ & $\begin{array}{l}109 \\
70.9 \\
45.2 \\
30.4 \\
\end{array}$ & $\begin{array}{l}128 \\
83.1 \\
48.1 \\
33.2 \\
\end{array}$ & $\begin{array}{l}88 \\
57.1 \\
42.7 \\
22.8 \\
\end{array}$ \\
\hline Pharmacies & $\begin{array}{l}\text { Count } \\
\text { Within occupational group (\%) } \\
\text { Within color code }(\%) \\
\text { Percentage of total }(\%) \\
\end{array}$ & $\begin{array}{l}11 \\
61.1 \\
2.5 \\
2.8 \\
\end{array}$ & $\begin{array}{l}9 \\
50 \\
3.4 \\
2.3 \\
\end{array}$ & $\begin{array}{l}10 \\
55.5 \\
4.8 \\
2.6\end{array}$ \\
\hline $\begin{array}{l}\text { Medical } \\
\text { technician }\end{array}$ & $\begin{array}{l}\text { Count } \\
\text { Within occupational group }(\%) \\
\text { Within color code }(\%) \\
\text { Percentage of total }(\%) \\
\end{array}$ & $\begin{array}{l}38 \\
50.6 \\
15.7 \\
9.87 \\
\end{array}$ & $\begin{array}{l}47 \\
62.6 \\
17.9 \\
12.2 \\
\end{array}$ & $\begin{array}{l}42 \\
56 \\
20.3 \\
11 \\
\end{array}$ \\
\hline $\begin{array}{l}\text { Non- } \\
\text { medical } \\
\text { technician }\end{array}$ & $\begin{array}{l}\text { Count } \\
\text { Within occupational group (\%) } \\
\text { Within color code }(\%) \\
\text { Percentage of total }(\%)\end{array}$ & $\begin{array}{l}11 \\
78.7 \\
2.5 \\
2.8\end{array}$ & $\begin{array}{l}8 \\
57.1 \\
3 \\
2.1\end{array}$ & $\begin{array}{l}5 \\
35.7 \\
2.4 \\
1.4\end{array}$ \\
\hline Admiration & $\begin{array}{l}\text { Count } \\
\text { Within occupational group }(\%) \\
\text { Within color code }(\%) \\
\text { Percentage of total }(\%) \\
\end{array}$ & $\begin{array}{l}30 \\
71.4 \\
12.4 \\
7.79 \\
\end{array}$ & $\begin{array}{l}25 \\
59.5 \\
9.4 \\
6.5 \\
\end{array}$ & $\begin{array}{l}24 \\
57.2 \\
11.6 \\
6.2 \\
\end{array}$ \\
\hline $\begin{array}{l}\text { Cleaners } \\
\text { and porters }\end{array}$ & $\begin{array}{l}\text { Count } \\
\text { Within occupational group }(\%) \\
\text { Within color code }(\%) \\
\text { Percentage of total }(\%) \\
\end{array}$ & $\begin{array}{l}23 \\
60.5 \\
9.5 \\
5.9 \\
\end{array}$ & $\begin{array}{l}15 \\
39.5 \\
5.6 \\
4.2 \\
\end{array}$ & $\begin{array}{l}16 \\
42.1 \\
7.7 \\
4.1 \\
\end{array}$ \\
\hline Total & $\begin{array}{l}\text { Count } \\
\text { Within occupational group }(\%) \\
\text { Within color cod }(\%) \\
\text { Percentage of total }(\%)\end{array}$ & $\begin{array}{l}241 \\
62.6 \\
100 \\
62.6 \\
\end{array}$ & $\begin{array}{l}266 \\
69.1 \\
100 \\
69.1 \\
\end{array}$ & $\begin{array}{l}206 \\
53.5 \\
100 \\
53.5 \\
\end{array}$ \\
\hline
\end{tabular}

a. Hospital healthcare knowledge about disposal of non-hazard health-care waste.

b.Hospital stuff knowledge disposal of objects that may be capable of causing punctures or cuts that may have been exposed to blood or body fluids.

c. Hospital healthcare knowledge disposal of very contagious health-care waste. 
Training all hospital personnel of healthcare staff is indispensable in the efforts to minimize the transmission of secondary infections. Continuing education are integral parts of the healthcare waste-management system. Periodic repetition, and Follow-up training of courses will provide an opportunity to instruct new employees, and "refresher" courses for existing employees can remind them of practices and inform about changes or new responsibilities and revising the scope of future refresher courses (WHO, 2014)

Paying attention to employee education about handling of healthcare waste before being a percentage of medical staff, the majority of cleaners and porters did not take such courses from 38 of the cleaners and porter only 2 take such courses. (table a.2)

According to the employee's courses that have been taken in handling hazard healthcare waste, on the job training program, the majority of cleaners and porter did not take such program, from 38 of the cleaners and porter only 8 take such courses, and 168 take such course from total 385 of selected sample in the survey (table b.2).

For the refreshing courses, from 38 of the cleaners and porter only 5 take such courses and 154 take such course from total 385 of selected sample in the study. Overall averages of hospital staff surveyed, cleaners and porters have the lowest percentage of staff have taken the refresher courses. When all of the other positions are combined, $40 \%$ of the staff have taken such courses (table c.2) 
Table 2: medical staff joined training programs

\begin{tabular}{|c|c|c|c|c|c|c|c|c|c|}
\hline & \multicolumn{3}{|c|}{$\begin{array}{c}\text { a. Back ground } \\
\text { education about health } \\
\text { care waste handling }\end{array}$} & \multicolumn{3}{|c|}{$\begin{array}{c}\text { b.Staff have course } \\
\text { when start work } \\
\text { handling }\end{array}$} & \multicolumn{3}{|c|}{ c.Refreshing courses } \\
\hline & Yes & No & Total & Yes & No & Total & Yes & No & Total \\
\hline $\begin{array}{l}\text { Doctors } \\
\text { C } \\
\text { WOG (\%) } \\
\text { W B G (\%) } \\
\text { S T (\%) }\end{array}$ & $\begin{array}{l}28 \\
63.6 \\
12.9 \\
7.3\end{array}$ & $\begin{array}{l}16 \\
36.3 \\
9.5 \\
4.3\end{array}$ & $\begin{array}{l}44 \\
100 \\
22.4 \\
31.4\end{array}$ & $\begin{array}{l}17 \\
38.6 \\
10.1 \\
4.4\end{array}$ & $\begin{array}{l}27 \\
61.4 \\
12.4 \\
7\end{array}$ & $\begin{array}{l}44 \\
100 \\
22.5 \\
11.4\end{array}$ & $\begin{array}{l}18 \\
40.9 \\
11.7 \\
4.7\end{array}$ & $\begin{array}{l}26 \\
59.1 \\
11.5 \\
6.7\end{array}$ & $\begin{array}{l}44 \\
100 \\
23.2 \\
11.4\end{array}$ \\
\hline $\begin{array}{l}\text { Nurse } \\
\text { C } \\
\text { WOG (\%) } \\
\text { W B G (\%) } \\
\text { S T (\%) }\end{array}$ & $\begin{array}{l}129 \\
84 \\
59 \\
33.5\end{array}$ & $\begin{array}{l}25 \\
16 \\
15 \\
6.4\end{array}$ & $\begin{array}{l}154 \\
100 \\
74 \\
39.9\end{array}$ & $\begin{array}{l}109 \\
70.8 \\
64.9 \\
38.3 \\
\end{array}$ & $\begin{array}{l}45 \\
29.2 \\
20.1 \\
11.7 \\
\end{array}$ & $\begin{array}{l}154 \\
100 \\
85 \\
50 \\
\end{array}$ & $\begin{array}{l}97 \\
63 \\
62.2 \\
25.2 \\
\end{array}$ & $\begin{array}{l}57 \\
37 \\
24.6 \\
14.8 \\
\end{array}$ & $\begin{array}{l}154 \\
100 \\
86.8 \\
40 \\
\end{array}$ \\
\hline $\begin{array}{l}\text { Pharmacies } \\
\text { C } \\
\text { WOG (\%) } \\
\text { W B G (\%) } \\
\text { S T (\%) }\end{array}$ & $\begin{array}{l}7 \\
39.9 \\
3 \\
1.8\end{array}$ & $\begin{array}{l}11 \\
61.1 \\
6.5 \\
1.6\end{array}$ & $\begin{array}{l}18 \\
100 \\
9.5 \\
3.4\end{array}$ & $\begin{array}{l}3 \\
16.7 \\
1.8 \\
0.8\end{array}$ & $\begin{array}{l}15 \\
83.3 \\
6.9 \\
3.9\end{array}$ & $\begin{array}{l}18 \\
100 \\
8.6 \\
4.7\end{array}$ & $\begin{array}{l}4 \\
22 \\
2.6 \\
1\end{array}$ & $\begin{array}{l}14 \\
78 \\
6 \\
3.6\end{array}$ & $\begin{array}{l}18 \\
100 \\
3.2 \\
4.6\end{array}$ \\
\hline $\begin{array}{l}\text { Medical } \\
\text { technician } \\
\text { C } \\
\text { WOG (\%) } \\
\text { W B G (\%) } \\
\text { S T (\%) }\end{array}$ & $\begin{array}{l}36 \\
48 \\
16.5 \\
9.3\end{array}$ & $\begin{array}{l}39 \\
52 \\
23.2 \\
10.1\end{array}$ & $\begin{array}{l}75 \\
100 \\
39.7 \\
19.4\end{array}$ & $\begin{array}{l}18 \\
24 \\
10.7 \\
4.7\end{array}$ & $\begin{array}{l}57 \\
76 \\
26.3 \\
14.8\end{array}$ & $\begin{array}{l}75 \\
100 \\
37 \\
19.5\end{array}$ & $\begin{array}{l}20 \\
26.7 \\
12.9 \\
5.2\end{array}$ & $\begin{array}{l}55 \\
73.3 \\
23.8 \\
14.3\end{array}$ & $\begin{array}{l}75 \\
100 \\
36.7 \\
19.5\end{array}$ \\
\hline $\begin{array}{l}\text { Non-medcal } \\
\text { technician } \\
\text { C } \\
\text { WOG (\%) } \\
\text { W B G (\%) } \\
\text { S T (\%) }\end{array}$ & $\begin{array}{l}4 \\
28.6 \\
2 \\
1\end{array}$ & $\begin{array}{l}10 \\
71.4 \\
6 \\
2.5\end{array}$ & $\begin{array}{l}14 \\
100 \\
8 \\
3.5\end{array}$ & $\begin{array}{l}3 \\
21.4 \\
1.8 \\
0.8\end{array}$ & $\begin{array}{l}11 \\
78.6 \\
5.1 \\
2.8\end{array}$ & $\begin{array}{l}14 \\
100 \\
6.9 \\
3.6\end{array}$ & $\begin{array}{l}2 \\
14.3 \\
1.3 \\
0.5\end{array}$ & $\begin{array}{l}12 \\
85.7 \\
5.2 \\
3\end{array}$ & $\begin{array}{l}14 \\
100 \\
6.5 \\
3.5\end{array}$ \\
\hline $\begin{array}{l}\text { Admiration } \\
\text { C } \\
\text { WOG (\%) } \\
\text { W B G (\%) } \\
\text { S T (\%) }\end{array}$ & $\begin{array}{l}11 \\
26 \\
5 \\
2.8\end{array}$ & $\begin{array}{l}31 \\
74 \\
18.4 \\
8\end{array}$ & $\begin{array}{l}42 \\
100 \\
33.4 \\
10.8\end{array}$ & $\begin{array}{l}10 \\
23.8 \\
5.9 \\
2.6\end{array}$ & $\begin{array}{l}32 \\
76.2 \\
14.7 \\
8.3\end{array}$ & $\begin{array}{l}42 \\
100 \\
20.6 \\
10.9\end{array}$ & $\begin{array}{l}8 \\
19 \\
5.2 \\
2\end{array}$ & $\begin{array}{l}34 \\
81 \\
14.7 \\
8.8\end{array}$ & $\begin{array}{l}42 \\
100 \\
19.9 \\
10.8\end{array}$ \\
\hline $\begin{array}{l}\text { Cleaners } \\
\text { C } \\
\text { WOG (\%) } \\
\text { W B G (\%) } \\
\text { S T (\%) }\end{array}$ & $\begin{array}{l}2 \\
5 \\
0.9 \\
0.5\end{array}$ & $\begin{array}{l}36 \\
95 \\
21.4 \\
9.3\end{array}$ & $\begin{array}{l}38 \\
100 \\
22.9 \\
9.8\end{array}$ & $\begin{array}{l}8 \\
21 \\
4.8 \\
2\end{array}$ & $\begin{array}{l}30 \\
79 \\
13.8 \\
7.7\end{array}$ & $\begin{array}{l}38 \\
100 \\
14.5 \\
9.7\end{array}$ & $\begin{array}{l}5 \\
2.2 \\
3 \\
1.3\end{array}$ & $\begin{array}{l}33 \\
86.8 \\
14.3 \\
8.7\end{array}$ & $\begin{array}{l}38 \\
100 \\
17.3 \\
10\end{array}$ \\
\hline $\begin{array}{l}\text { C } \\
\text { WOG (\%) } \\
\text { WBG (\%) } \\
\text { SHT (\%) }\end{array}$ & $\begin{array}{l}217 \\
56.1 \\
100 \\
56.1\end{array}$ & $\begin{array}{l}168 \\
43.6 \\
100 \\
43.6\end{array}$ & $\begin{array}{l}385 \\
100 \\
100 \\
100\end{array}$ & $\begin{array}{l}168 \\
43.6 \\
100 \\
43.6\end{array}$ & $\begin{array}{l}217 \\
56.4 \\
100 \\
56.4\end{array}$ & $\begin{array}{l}385 \\
100 \\
100 \\
100\end{array}$ & $\begin{array}{l}154 \\
40 \\
100 \\
40\end{array}$ & $\begin{array}{l}231 \\
60 \\
100 \\
60\end{array}$ & $\begin{array}{l}385 \\
100 \\
100 \\
100\end{array}$ \\
\hline
\end{tabular}

C:Count

WOG:Within occupational group (\%) 
J. Environ. Sci.

Institute of Environmental Studies and Research - Ain Shams University

WBG:Within back ground (\%)

SHT:Share of total $(\%)$

a. Hospital staff enter pre-woking training programs. b. Hospital staff enters on job training programs. c. Hospital staff joins refreshment courses and continuous updating programs.

Safety and precaution of hospital staff: The hepatitis B virus disease can be avoided by vaccination, which has been available since 1980. Numerous studies have shown that the vaccine is effective in preventing all of the forms of infection with hepatitis B virus. Although this vaccination is safe, effective and cost-efficient, it is still under-used (ICRC, 2011)

The majority of staff has been fully inoculated against hepatitis B; from 385 staff survey 86 not take the vaccine, 44 not sure. And the majority of hospital staff indicates the knowledge of the most important method to prevent the spread of infection.

Injury reporting system: Regard to $(\mathrm{KMOH})$ statistic during 2015 injury from needle stick was 314, and 34 exposures to blood. This statistic indicates the reported incident, while unreported cases are unknown.

A study of (Omar and Abdo, 2015) conclude that Needle stick injuries are the most common exposure among HCP in Kuwait, and nurses are the most frequently involved HCP category. A good proportion of exposures could be easily prevented. HBV vaccination coverage is incomplete.

The survey detect Type of injury was $30.3 \%$ infection ,33.3 \% sharp injury , $6.1 \%$ chemical exposure , and $33.3 \%$ back pain from heavy lifting. The majority of injured accident does not report, $70.3 \%$ of total accident doesn't reporting. 
The accident of injury varies from Poor disposal, individual carelessness/accident, and some worker cannot remember, or other reason. And $36 \%$ of them don't report the accident.

Incinerator: Medical waste classify to hazardous and non-hazardous waste. According to Statistic of Kuwait's Ministry of Health (MOH), the average generation medical waste is $2,921,710.6 \mathrm{~kg} /$ year.

In state of Kuwait there is three major central incinerators, two of them are in Alshuaibah and one in $\mathrm{Kbd}$, these incinerator capacity not less than $500 \mathrm{~kg}$ / h (12 tons per day), and able for 24 hours (7 days/week) continuous operation.

The operation of incineration is done as the following:

- Hazards healthcare waste enters into the feeding system by automatic mechanical feeder system.

- Hazards healthcare waste transfer to the primary combustion chamber the temperature given is 800 to $90000 \mathrm{C}$, and it turns solid waste into gas fly ash, and bottom ash.

- Bottom ash collected and removes by automatic bottom ash removal (Automatic de aching) to landfill.

- Accelerator pedal is being active in the secondary combustion chamber for 2 minutes at a temperature $1000-120000 \mathrm{C}$ and it's potential to be upgraded to 14000C.

- Very hot gases move to cooling down the chamber with temperature of $1200^{\circ} \mathrm{C}$ to $200^{\circ} \mathrm{C}$.

- Then inter gases to chemical processing chamber (reactor) which pass the lime to neutralize $\mathrm{pH}$ and pass on active carbon to pull toxic substances. 
- Flay ash filter and removed by scrubber filter, then sends to landfill.

- The remaining air is getting out by the chimney. (Fig 1)

Also, it located on the main propeller of the incinerator and is considered the heart of the incinerator air to enter the burning process to finish and there are detectors in the combustion chambers its function to adjust the temperature at high temperature the system shuts down the fuel and run the incinerator on the energy generated by cutting waste

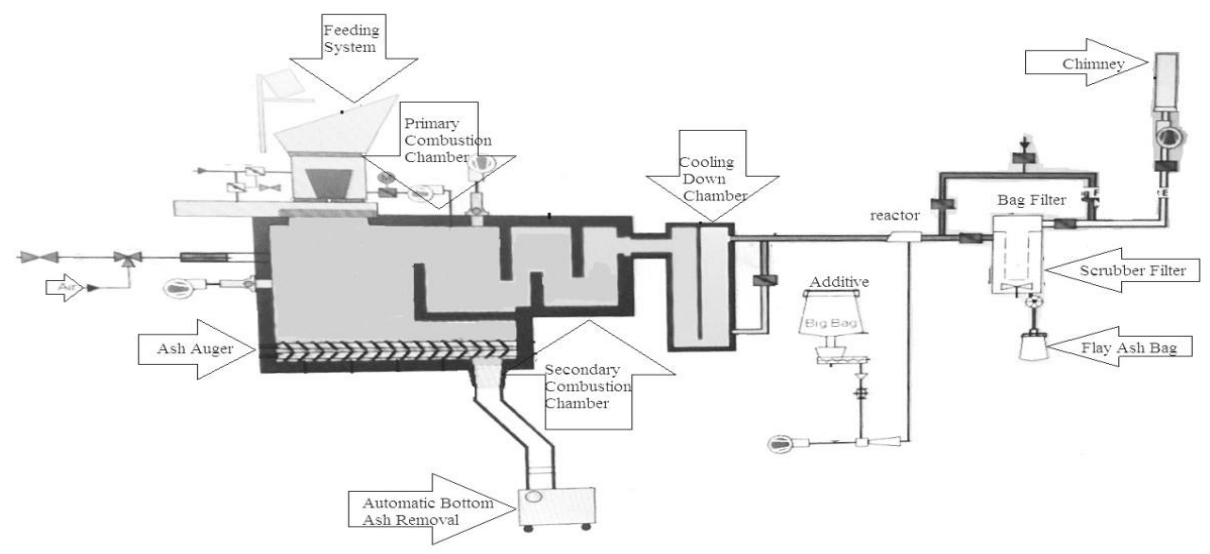

Figure 1: Components of incinerator

Emission monitoring program: Incineration can destroy or inactive infectious waste, offer significant ( $>90 \%)$ mass and mass reduction of the barren, and render materials (syringes, etc.) unusable (Drive, 2004)

Although Incinerations of hazard healthcare waste effective way to cut down the size of waste and take rid of infection contaminated, but it produces polluted materials. The polluted material is: 
- Ash (Lower and upper).

- Gaseous emissions (vehicles dioxin and furans, precision, carbon monoxide, nitrogen oxides, particulate matter, carbon dioxide, hydrogen chloride, lead, cadmium, mercury).

Emission monitoring program concern on continues and individual measurement. Continuous measurement automatically done in the control room for (HCL, HF, SO2, NOx, CO), all measured data read and simultaneously evaluated inside the installation, using automatically computing system.

This study concern on field monitoring of the individual measurement for stack emission monitoring for dioxin, furan, heavy metal, and particulate matter emissions, the study was done during the year 2015 and 2016 focused on 3 incinerator of healthcare waste in the state of Kuwait (SHUAIBA1, SHUAIBA2, and KBD). A total of (9) samples was picked from these healthcare waste incinerators under normal operating conditions, all gas emissions should be in allowing limits set by (KEPA).

Comparative survey of total dioxin and furan compound (PCDD's and PCDF's) from stack of central incinerators in State of Kuwait :Kuwait Environmental Public Authority (KEPA) set a standard for total dioxin and furan compound (PCDD's and PCDF's), $\left(0.1 \mathrm{ng} / \mathrm{m}^{3}\right)$ to limit pollutant that emit to air. This study on 3 central incinerators in the state of Kuwait indicates the following result for total dioxin and furan compound (PCDD's and PCDF's). 
Total dioxin and furan compound (PCDD's and PCDF's) from stack of central incinerators: Samples collected from Shuaiba1 incinerator (Table 3 .a) shows that the result of total dioxin and furan compound (PCDD's and PCDF s) are $0.05,0.075$, and $0.081 \mathrm{ng} / \mathrm{m}^{3}$. The resultof total dioxin and furan compound (PCDD's and PCDF's) indicates that the emanations of such compound are within the Kuwait Environment Public Authority (KEPA) permissible limit.

Samples collected from Shuaiba2 incinerator (Table 3.b) shows that the result of total dioxin and furan compound (PCDD's and PCDF's) are 0.067, 0.096 , and $0.059 \mathrm{ng} / \mathrm{m} 3$. Sample 1 indicates that the result of total dioxin and furan compound (PCDD's and PCDF's) are within the Kuwait Environmental Public Authority (KEPA) permissible limit. Sample 3 result indicates that it's close to limit that set by the Kuwait Environment, Public Authority (KEPA), Kuwait Ministry of health stop incineration in a Shuaiba2 incinerator after this result to do some maintenance. The result of (PCDD's and PCDF's) is $059 \mathrm{ng} / \mathrm{m} 3$ after maintenance, which showed a marked improvement in the amount of such compound emitted.

Samples collected from Kbd incinerator (Table 3.c) shows that the result of total dioxin and furan compound (PCDD's and PCDF's) are 0.086, 0.0806, and $0.083 \mathrm{ng} / \mathrm{m}^{3}$. The result of total dioxin and furan compound (PCDD's and PCDF s) indicates that the emissions of such compound are within the Kuwait Environment Public Authority (KEPA) permissible limit. 
A simple comparison between 3 incinerators sample averages of (PCDD's and PCDF's) emotions had been done (Fig 2) indicate that the Kbd incinerator has highest concentration of (PCDD's and PCDF's).

Table 3: Total dioxin and furan compound (PCDD's and PCDF's)

Concentrations,a.Shuaiba1, b.Shuaiba2,and c. Kbd incinerator.

\begin{tabular}{|l|l|l|l||}
\hline $\begin{array}{c}\text { Sample } \\
\text { No. }\end{array}$ & $\begin{array}{c}\text { a.Shuaiba1 } \\
\text { incinerator } \\
\text { CONCENTRATION } \\
\mathrm{ng} / \mathrm{m}^{3}\end{array}$ & $\begin{array}{c}\text { b.Shuaiba2 } \\
\text { incinerator } \\
\text { CONCENTRATION } \\
\mathrm{ng} / \mathrm{m}^{3}\end{array}$ & $\begin{array}{c}\text { c.Kbd } \\
\text { incinerator } \\
\text { CONCENTRATION } \\
\mathrm{ng} / \mathrm{m}^{3}\end{array}$ \\
\hline \hline 1 & 0.05 & 0.067 & 0.086 \\
\hline 2 & 0.075 & 0.096 & 0.0806 \\
\hline 3 & 0.081 & 0.059 & 0.083 \\
\hline Average & 0.0686 & 0.074 & 0.0832 \\
\hline
\end{tabular}

Note: (KEPA) standard is $0.1 \mathrm{ng} / \mathrm{m}^{3}$

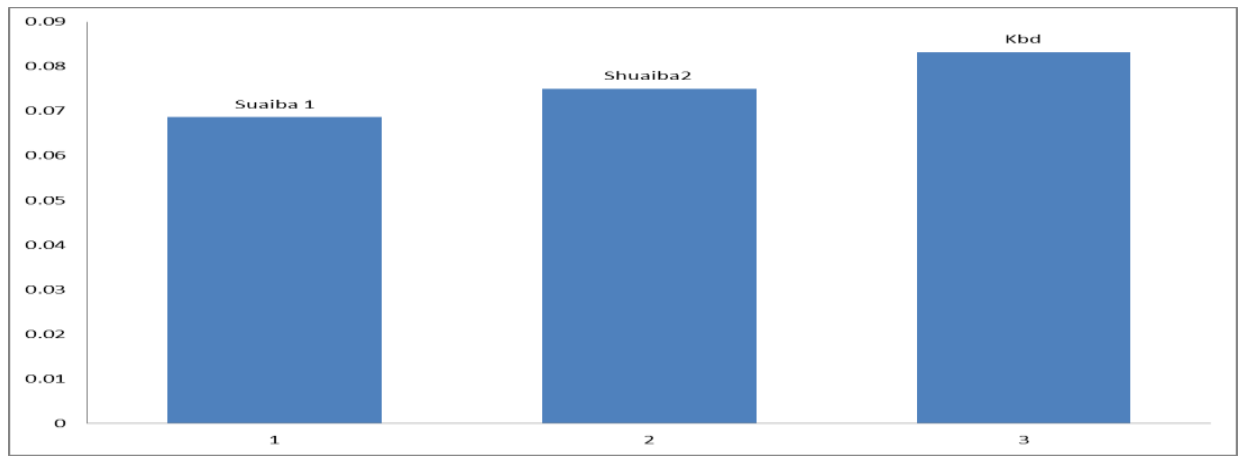

Figure 2: Mean concentrations of Total dioxin and furan compound (PCDD's and PCDF's) of incinerators

Comparative study of Total Dioxin and Furan Compound Mean (PCDD's And PCDF's) By Years :By working out averages of Dioxin and Furan Compound for each year of 2014, 2015, and 2016, the Result shows that average of (PCDD'S AND PCDF'S) increase by the time. And (Fig 3) 
J. Environ. Sci.

Institute of Environmental Studies and Research - Ain Shams University

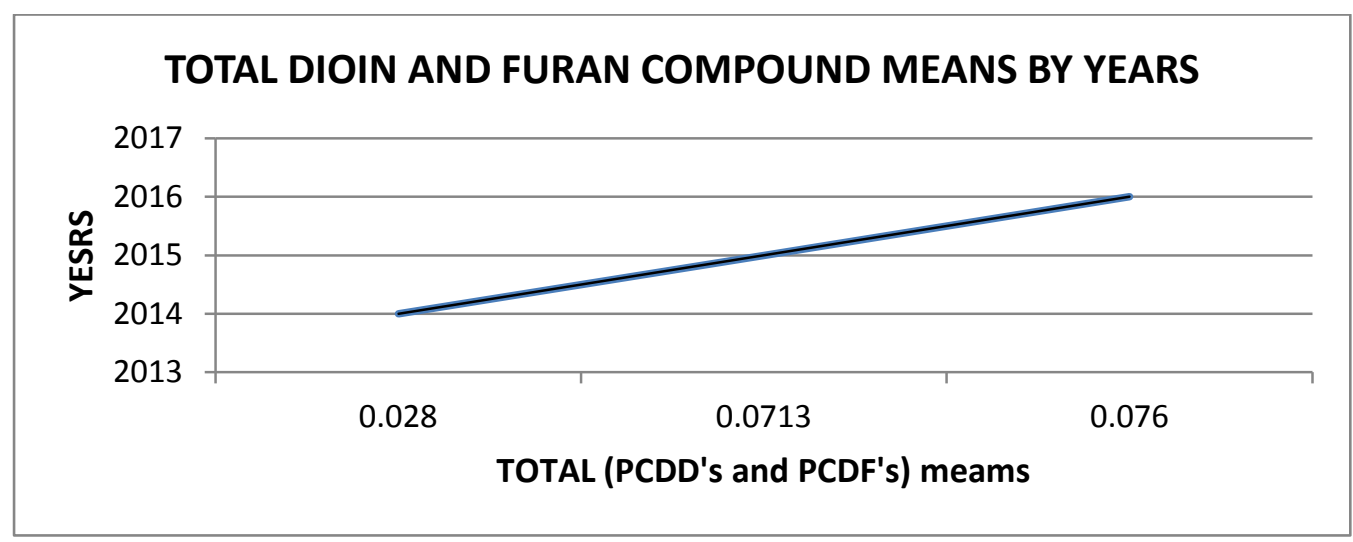

Figure 3 The relation between Total Dioxin and Furan Compound Mean (PCDD's And PCDF's) with the years.

Comparative study of the relation between Generation healthcare waste with Total dioxin and furan compound (PCDD's and PCDF's): Population growth has also been accompanied by the increase and diversification of population activities, which have increased and diversified by increasing the population, and increased the amount of solid waste resulting from increased consumption. (Muhish, 2001)

By calculating averages (PCDD's and PCDF's) of each incineration (Table 4), the result shows that there is a positive relation between two variables, that means of increasing the generation healthcare waste the (PCDD's and PCDF's) increase (Fig4). 
Table 4: Averages of 3 central incinerators with emissions of (PCDD's and PCDF's)

\begin{tabular}{|l|l|l|l|}
\hline & \multicolumn{1}{|c|}{ Location } & \multicolumn{1}{|c|}{$\begin{array}{c}\text { Concentration } \mathbf{n g} / \mathbf{m}^{3} \\
\text { mean }\end{array}$} & \multicolumn{1}{|c|}{$\begin{array}{c}\text { Generation waste } \\
(\mathbf{k g}) \text { mean }\end{array}$} \\
\hline 1 & SHUAIBA1 & 0.069 & 80099 \\
\hline 2 & SHUAIBA2 & 0.075 & 98787 \\
\hline 3 & KBD & 0.0833 & 135684 \\
\hline
\end{tabular}

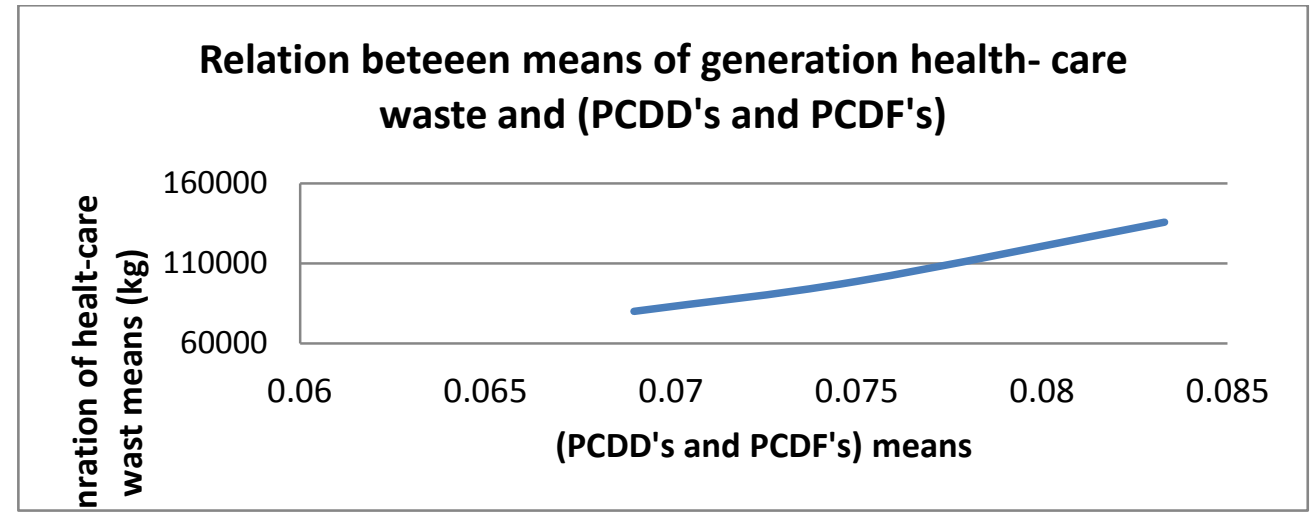

Figure 4: Positive relation between Generation health-care waste and (PCDD's and PCDF's)

Result of heavy metal parameter: All collected sample result test of heavy metal $(\mathrm{Pb}, \mathrm{Hg}$, and $\mathrm{Cd})$ and particular matter shows that the concentration is within (KEPA), (Tables 5,6and 7).

Table 5: Mean concentrations of heavy metal from flay ash in Shuaiba1 incinerator

\begin{tabular}{|l|c|c|c|c|}
\hline $\begin{array}{c}\text { Sample } \\
\text { No }\end{array}$ & $\begin{array}{c}\mathbf{P b} \\
\mathbf{m g} / \mathbf{m}^{\mathbf{3}}\end{array}$ & $\begin{array}{c}\mathbf{H g} \\
\mathbf{m g} / \mathbf{m}^{\mathbf{3}}\end{array}$ & $\begin{array}{c}\mathbf{C d} \\
\mathbf{m g} / \mathbf{m}^{\mathbf{3}}\end{array}$ & $\begin{array}{c}\text { Particulate mater } \\
\mathbf{m g} / \mathbf{m}^{\mathbf{3}}\end{array}$ \\
\hline $\mathbf{1}$ & 0.0004 & $<0.0003$ & $<0.0003$ & 1.85 \\
\hline $\mathbf{2}$ & $<0.0002$ & $<0.0002$ & $<0.0002$ & 1.21 \\
\hline $\mathbf{3}$ & $<0.0001$ & $<0.0002$ & $<0.0001$ & 2.39 \\
\hline Average & $<0.00023$ & $<0.00023$ & $<0.0002$ & 1.81 \\
\hline \multicolumn{4}{|c|}{ Vol. 39, No.1, Spt. 2017 } \\
\hline
\end{tabular}


Table 6: Mean concentrations of heavy metal from flay ash in Shuaiba2 incinerator

\begin{tabular}{|l|l|l|l|l|}
\hline $\begin{array}{c}\text { Sample } \\
\text { No }\end{array}$ & \multicolumn{1}{|c|}{$\begin{array}{c}\mathbf{P b} \\
\mathrm{mg} / \mathrm{m}^{3}\end{array}$} & \multicolumn{1}{|c|}{$\begin{array}{c}\text { Hg } \\
\mathrm{mg} / \mathrm{m}^{3}\end{array}$} & $\begin{array}{c}\text { Cd } \\
\mathrm{mg} / \mathrm{m}^{3}\end{array}$ & $\begin{array}{c}\text { Particulate mater } \\
\mathrm{mg} / \mathrm{m}^{3}\end{array}$ \\
\hline \hline $\mathbf{1}$ & 0.0008 & 0.0006 & $<0.0003$ & 1.48 \\
\hline $\mathbf{2}$ & $<0.0001$ & $<0.0001$ & $<0.0001$ & 2.09 \\
\hline $\mathbf{3}$ & $<0.0002$ & $<0.0002$ & $<0.0002$ & 2.09 \\
\hline Average & 0.000367 & 0.0003 & 0.0002 & 1.887 \\
\hline
\end{tabular}

Table 7: Mean concentrations of heavy metal from flay ash in Kbd incinerator

\begin{tabular}{|l|c|c|c|c|}
\hline $\begin{array}{c}\text { Sample } \\
\text { No }\end{array}$ & $\begin{array}{c}\mathbf{P b} \\
\mathrm{mg} / \mathrm{m}^{3}\end{array}$ & $\begin{array}{c}\mathbf{H g} \\
\mathrm{mg} / \mathrm{m}^{3}\end{array}$ & $\begin{array}{c}\mathbf{C d} \\
\mathrm{mg} / \mathrm{m}^{3}\end{array}$ & $\begin{array}{c}\text { Particulate mater } \\
\mathrm{mg} / \mathrm{m}^{3}\end{array}$ \\
\hline \hline $\mathbf{1}$ & 0.0009 & $<0.0003$ & $<0.0003$ & 1.84 \\
\hline $\mathbf{2}$ & $<0.002$ & $<0.002$ & $<0.002$ & 1.89 \\
\hline $\mathbf{3}$ & $<0.0001$ & $<0.0001$ & $<0.0001$ & 2.27 \\
\hline Average & 0.001 & 0.0008 & 0.0008 & 2 \\
\hline
\end{tabular}

Note: (KEPA) standard is $0.5 \mathrm{mg} / \mathrm{m}^{3}$ for Lead $(\mathrm{Pb}), 0.05 \mathrm{mg} / \mathrm{m}^{3}$ for Mercury $(\mathrm{Hg})$ and $0.05 \mathrm{mg} / \mathrm{m}^{3}$ for Cadmium $(\mathrm{Cd})$.

Note: (KEPA) standard is $34.0 \mathrm{mg} / \mathrm{m}^{3}$

\section{Bottom ash:}

The incineration process will remain on of the most viable methods for administration of medical hazard waste. Incineration reduces the original volume by $65-70 \%$, and generates bottom ash (BA) and fly ash (FA) (Lombardi, 1998)

Among 3 incinerations in the state of Kuwait the calculation shows that the incineration reduces volume of healthcare waste to $89 \%$ (Table 8). 
Table 8 Total volume of botoom ash $\mathrm{kg}$ to total volume of incinirated waste $\mathrm{kg}$ in 3incinerations (2016)

\begin{tabular}{|c|c|c|}
\hline Month & Incinerated waste (kg) & Bottom ash (kg) \\
\hline \hline Jan & 310,070 & 202,60 \\
\hline Feb & 321,293 & 107,00 \\
\hline Mar & 344,869 & 153,10 \\
\hline April & 315,126 & 721,0 \\
\hline May & 288,769 & 157,00 \\
\hline Jun & 243,564 & 683,0 \\
\hline Jul & 323,353 & 255,20 \\
\hline Aug & 363,473 & 176,10 \\
\hline Sep & 311,563 & 196,50 \\
\hline Oct & 373,277 & 374,20 \\
\hline Nov & 290,937 & 282,00 \\
\hline Dec & 351,430 & 206,30 \\
\hline Total & $2,157,683$ & $2,250,40$ \\
\hline$\%$ & & 10.4 \\
\hline
\end{tabular}

7 Sample collected to indicate leachate concentrations of hazardous chemical substance (heavy metal), according to the limits allowed for hazardous heavy metal (Table5.14) all results shows that bottom ash above limits. Bottom ash classifies as very hazard waste (Table 9).

Although the incinerations are a very effective means to cut down the size of healthcare waste, but the bottom ash classify to very hazard waste. The average concentration of $\mathrm{Cr}$ in 7 samples of bottom ash is $6.47 \mathrm{mg} / \mathrm{L}$ which is above the limits. Bottom ash classify as hazard waste. 
J. Environ. Sci.

Institute of Environmental Studies and Research - Ain Shams University

Table 9: Botom ash hevy metal concentration $\mathrm{mg} / \mathrm{L}$ result

\begin{tabular}{|c|c|c|c|c|c|c|c|c|c|}
\hline & Parameter & $\begin{array}{c}\text { Limits } \\
\mathbf{m g} / \mathbf{L}\end{array}$ & $\begin{array}{c}\mathbf{( 1 )} \\
\mathbf{m g} / \mathbf{L}\end{array}$ & $\begin{array}{c}\mathbf{( 2 )} \\
\mathbf{m g} / \mathbf{L}\end{array}$ & $\begin{array}{c}\mathbf{( 3 )} \mathbf{m g} / \mathbf{L} \\
\mathbf{m g} / \mathbf{L}\end{array}$ & $\begin{array}{c}\mathbf{( 5 )} \\
\mathbf{m g} / \mathbf{L}\end{array}$ & $\begin{array}{c}\mathbf{6}) \\
\mathbf{m g} / \mathbf{L}\end{array}$ & $\begin{array}{c}\mathbf{7}) \\
\mathbf{m g} / \mathbf{L}\end{array}$ \\
\hline \hline 1 & $\mathrm{Ba}$ & 10 & 4.775 & 301.70 & 2.500 & 3.210 & 2.100 & 3.100 & 2.670 \\
\hline 2 & $\mathrm{Cr}$ & 5.0 & 6.130 & 5.500 & 5.300 & 7.00 & 5.220 & 5.800 & 5.320 \\
\hline 3 & $\mathrm{Ni}$ & 10 & 0.993 & 1.900 & 0.813 & 1.100 & 0.520 & 0.260 & 1.100 \\
\hline 4 & $\mathrm{~Pb}$ & 5.0 & - & 1.00 & - & - & - & - & - \\
\hline 5 & $\mathrm{Cd}$ & 0.5 & 0.029 & 0.150 & 0.043 & 0.001 & 0.012 & 0.30 & 1.00 \\
\hline
\end{tabular}

Landfill: In the state of Kuwait there are main two types of landfill, inert waste landfill, and hazardous waste landfill. Bottom and fly ash collected from healthcare waste incineration classify as solid hazard waste that bridge in a hazardous waste landfill.

Thither are many possible environmental problems associated with landfill, these troubles are often long term and include possible contamination of land water and surface water regimes, the uncontrolled migration of landfill gas and generation of aroma, noise and visual nuisance.

Hazard land fill designed to provide as possible effective control measures to reduce negative effects on the surroundings.Bottom and fly ash collected in well closed containers and bridge in separated cells.

abstract In light of the protection of the environment from the dioxin and furan depletion, some measures should be taken, namely the continuous maintenance of incinerators, raising the awareness of workers in the health sector for proper sorting, minimizing the quantities of medical waste and providing an integrated administrative system. For waste separation 
operations, and cutting technology can be introduced as a supportive method for the treatment of medical waste. To reduce file quantities and facilitate data retrieval in the future, researchers and decision makers must provide a database and introduce the scanner system in the process of weight and transport of medical waste. It is also recommended to establish an electronic link between those responsible for the treatment of hazardous medical waste.

\section{REFERENCES}

Alhumoud, and Alhumoud, H. (2007). An analysis of Trends Relatedto Hospital Solid Wastes Managemenr In Kuwait. An I nternational Journal 18,502-513.

Amfo-Out.R, K. A. (2015). Comparative Study Of Heavy Metals In Bottom Ash From Incinerators And Open Pit From Healthcare Facilities In Ghana. A Journal of Environmental Research, 3(1):050-056.

Batterman, S. (2004). Assessment of Small-Scale Incinerators for Health Care Waste.Water Sanitation and Health, Department of Protection of the Human Environment. World Health Organization, Geneva.

Drive, A. A. (2004). Assessment of Small-Scale Incinerators for Health Care Waste. Stuart Batterman Environmental Health Sciences University of Michiga, Geneva 27, Switzerland By Stuart Batterman Environmental Health.

ICRC. (2011). Medical Waste Management. International Committee of the red cross, 121 Geneva, Switzerland.ICRC,Novemper 2011.

Lombardi, F. (1998). Mechanical and leaching properties of cement solidified hospital solid waste incinerator fly ash. Waste Management, Science \&Technology 18(2): 99-106.

Muhish, N. A. (2001). Health effects of air and water pollution in the capital Sana'a. Sana'a: Ain Shams University. 
Omar A.A. Abdo N.M.b, . S.-M. (2015). Occupational Injuries Prone to Infectious Risks amongst Healthcare Personnel in Kuwait: A Retrospective Study. Kuwait Med J.

Shortell, S. M., \& Kaluzny, A. D. (1988). Health Care Management (Vol. 2nd). New York: Delmar Publishers Inc.

WHO. (2014). Safe management of wastes from health-care activitie 2nd edition,

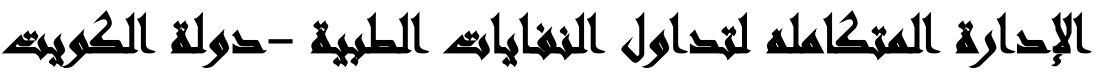

[1]

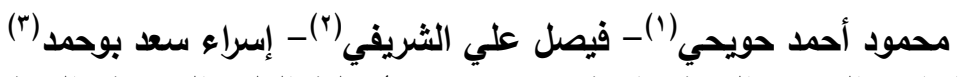

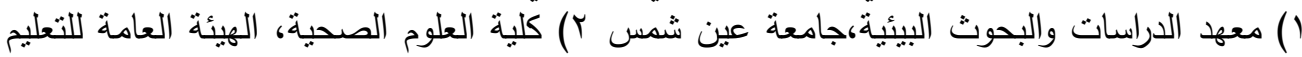
النطبيقي والتدريب r) وزارة الصحة، الكويت

\section{المستيلنص}

الهدف من هذا البحث هو ايجاد بدائل صديقة للبيئة من خلال تطبيقات الادارة المتكامله لتداول

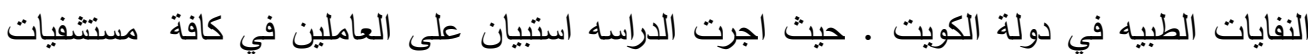
دولة الكويت الحكومية ( مبارك الكبير - الصباح- العدان - الجهراء- الفروانية - والاميري).

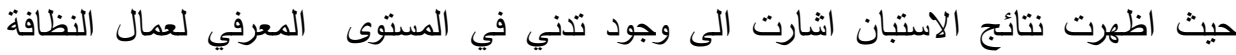
والاداريين في عملية التداول بينما كان طاقم التمريض على مستوى عال من الان المعرفة فئفي كيفية التداول

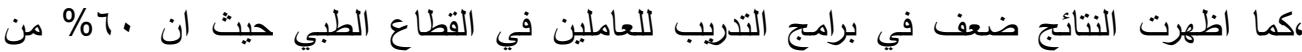

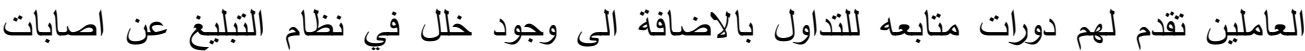

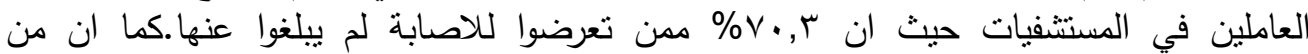

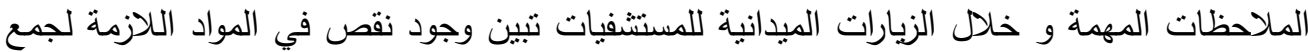
والتخلص السليم من النفايات الطبيه.

في دولة الكويت يتم التخلص من النفايات الطبيه بطريقتن وهما اما التعقيم للمواد المراد اعادة التهاد

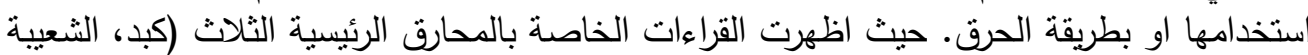

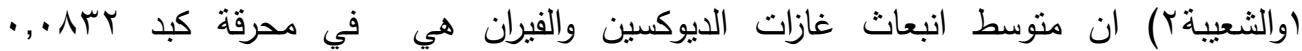

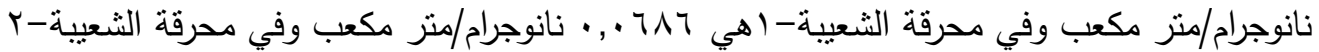

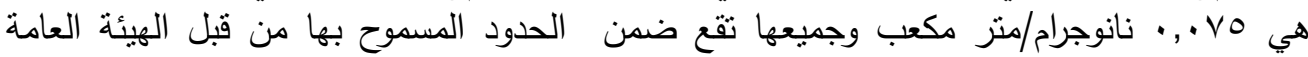

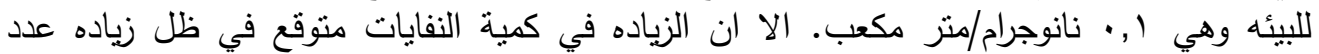




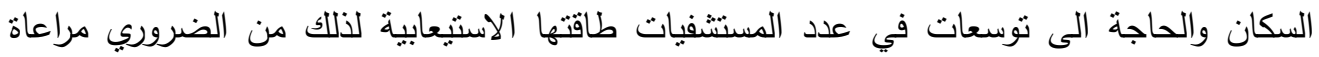

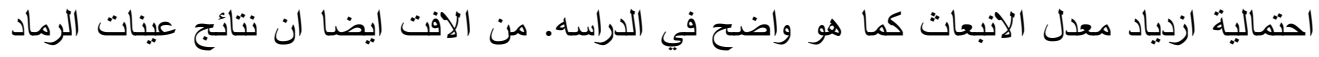

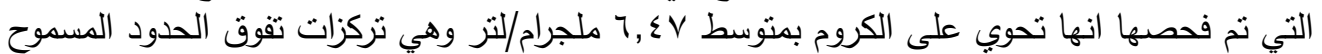

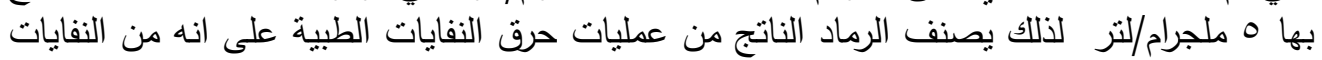
الصلبة شديدة الخطورة، ويتم تجميعه يدويا ونقلة للمدافن وردمة في موقع خلايا النفايات الخطرها

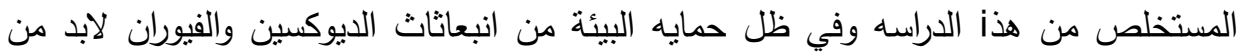

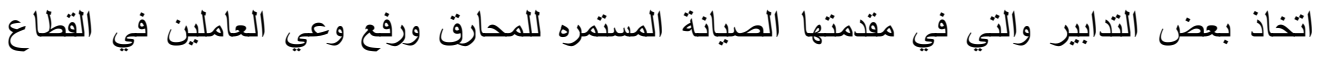

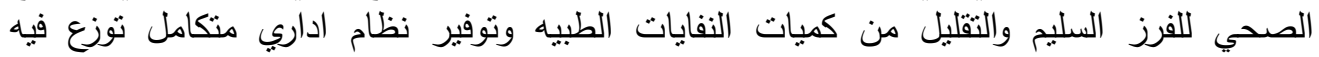
المسؤوليات لمتابعة عملية تداول النفايات وتوفير المواد اللازمة لعمليات فصل النفائات النفاتيات كما يمكن

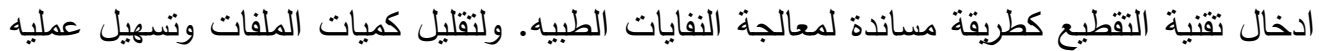

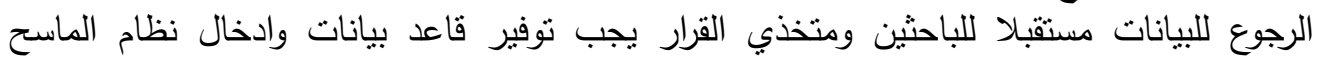

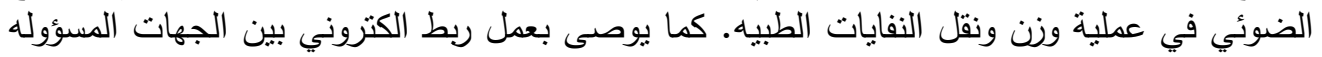
عن معالجة النفايات الطبيه الخطره ـ فلن ونائ 